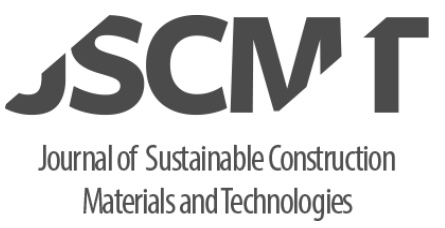

J. Sustain. Construct. Mater. Technol. 1(2) (2016) 60-63
Journal of Sustainable Construction Materials and Technologies

\title{
Roof Surface Color and Its Influence on Indoor Temperature
}

\author{
Jana Šabíková ${ }^{1, a, *}$ Lucia Krčmárová $^{1, \mathrm{~b}}$ \\ ${ }^{1}$ STU, Civil Engineering Faculty, dept. of Building Services, Radlinského 11, 81005 Bratislava, Slovakia \\ ajana.sabikova@stuba.sk, blucia.krcmarova@gmail.com
}

Received January 8, 2016, accepted March 20, 2016

\begin{abstract}
The paper presents results of simplified small-scale modelling of three buildings with different roof colour - covering. The aim of the measurement is to compare the influence of different roof covering (material, colour) onto the indoor temperature. The models are very simplified, used only to compare results among themselves, especially heat gains via conduction, and not between models and the real buildings under real conditions.
\end{abstract}

Keywords: solar gains, colour, model

\section{Introduction}

The energy saving nowadays plays an important role as has already been for many years. There are already known ways how to come to such a solution. One of the them considers savings during summer ( hot weather) due to neccesity to cool down buildings. Therefore it is very important to considere this aspect already during the building design phase. Utilization of passive cooling offers, for instance, proper orientation towards Cardinal points, shadings, proper glassing, and many other tools, including colour. The colour „,counts“ in the calculation of cooling load, as external solar gain through non-ransparent structures. The simplified caculation method is given, for instance, in Slovak standard STN 7305 48:1986 [1]. The amout of transphered gains into interior is

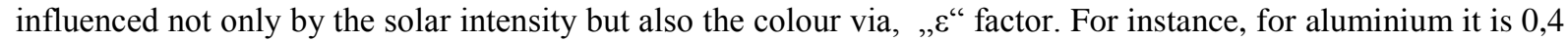
whereas 0,9 goes to red brick [2]. How high the impact could be in reality, was the targit for a small-scale experiment presented further which was done as a of diploma work [3].

The theme of modelling effect of colour on interior temperature is not the latest idea. It has been done, for instance, by Givoni [4] 40 years ago with the result the low heat capacity envelope is more dependant on curface colour than high capacity ones. The experiment also resulted in the fact that in such a case indoor air temeprature is influenced by ventilation and direct solar radiation. Later, Bansal [5] came with results of modelling and simmulation of the colour effect on indoor thermal comfort, with $6^{\circ} \mathrm{C}$ temperature diference, during summer, between black and white combinations.

\subsection{Description/ Methodology}

The scale used for modelling three („open space“) buildings was 1:24. Since the purpose of the experiment was not comparison between real and model conditions but among scaled buildings

\footnotetext{
* Corresponding author. Tel: +421 (2) 59274631

E-mail address: jana.sabikova@stuba.sk (J. Šabíková)

https://doi.org/10.29187/jscmt.2017.7
} 
themselves, the wall, floor and roof basis was the same, made from plywood. Each model has windows, shaded at the level of the second floor. The difference was in the last layer of the roof. The alternatives were as follows: a) aluminium, b) „Tatrafoil“ - rooffoil, and c) green roof (soil, grass, moss) (Fig. 1).

The experiment was running in Bratislava (Slovakia), at the end of April, beginning of May 2015. During those days the weather conditions varied a lot, from sunny and warm to rainny, cold, and windy).

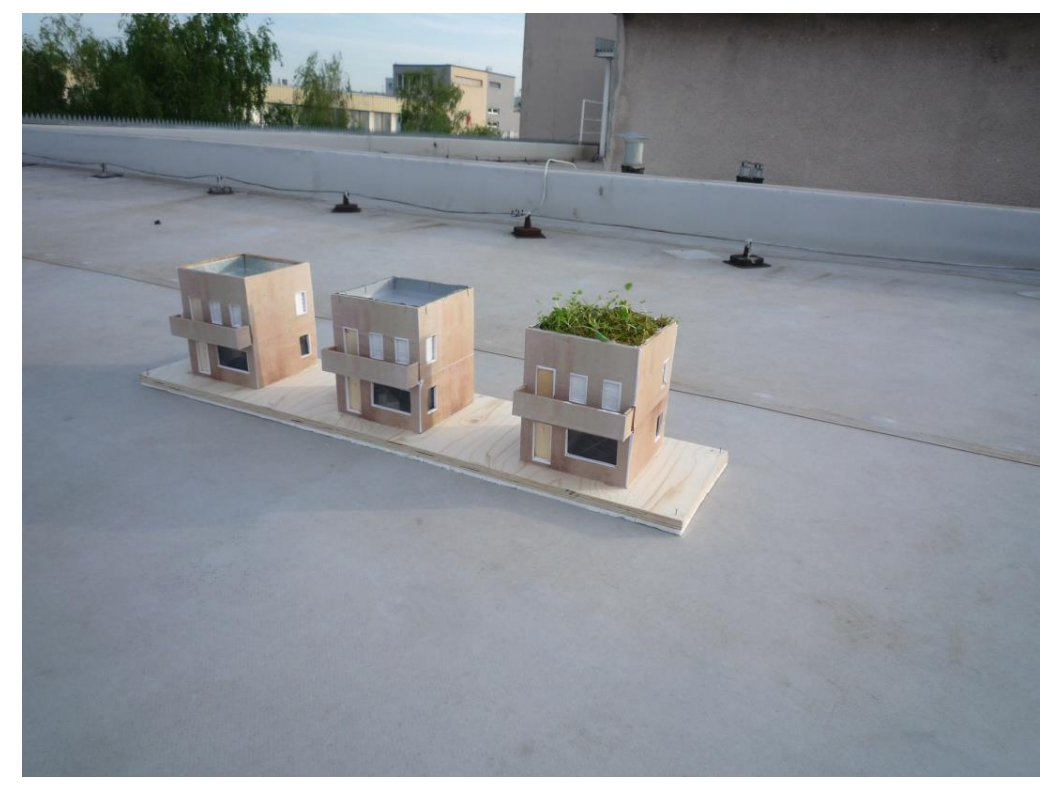

Figure 1. Small scale models of buildings (author: L. Krčmárová)

As far as the measured parameters are concerned, there were three of them, the indoor air temperature, surface roof temperature, and humidity. At the same time the outdoor temperature was monitored. The measuring instruments - thermo and humidity sensors (Cometsystem, SO122) were used (Fig. 2). The time interval was set up to 60 minutes.

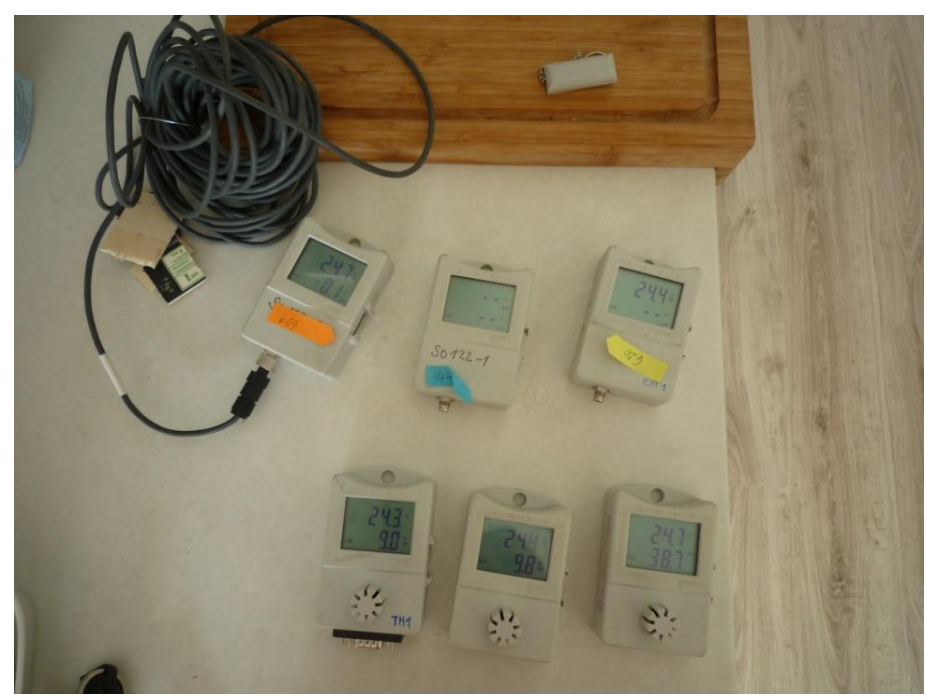

Figure 2. Small scale models of buildings (author: L. Krčmárová)

To avoid the possible influence of the indoor air temperature onto the ceiling surface one, the sensors were insulated from the bottom part. 


\section{Results}

Based on the logged data during the period between April $27^{\text {th }}$ and May $11^{\text {th }} 2015$, the mathematical evaluation followed. As expected, the lowest values during the day were measured in the case of green roof, $34^{\circ} \mathrm{C}$ for the indoor air temperature and $37 \quad{ }^{\circ} \mathrm{C}$ for the temperature of the ceiling. A bit higher temperatures were obtained in the case of the aluminium. The highest, among the three materials, was the temperature of the foil, $35^{\circ} \mathrm{C}$ for the indoor air and $39{ }^{\circ} \mathrm{C}$ for the celing (Fig. 3).

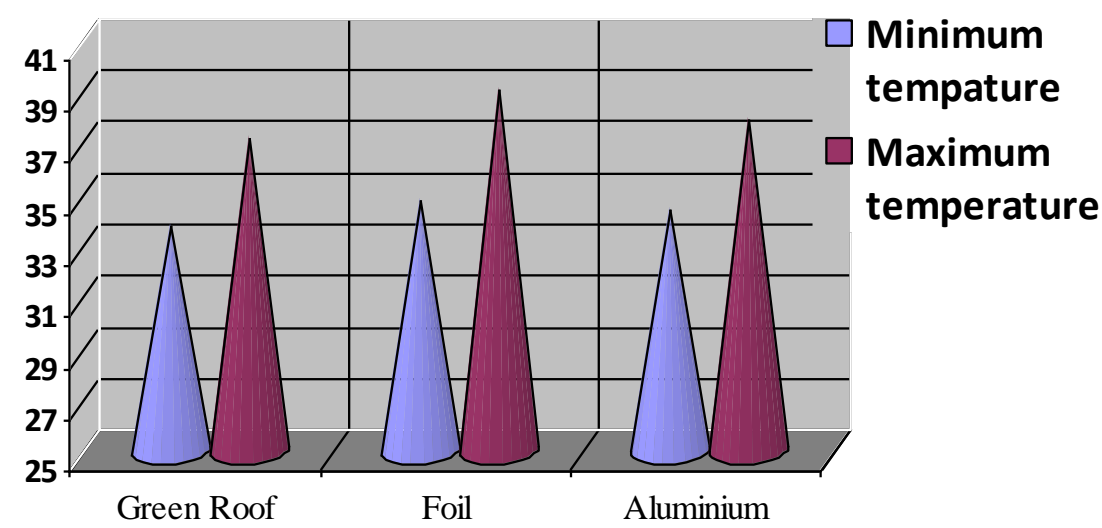

Figure 3. Minimum and maximum measured temperatures during day hours for 3 different types of roof coverings.

Figure 4. gives an example of measured temperatures in the case of a building with green roof. As seen, the indoor air, and roof temperatures follow outdoor temperature, its peak values. The straight values of the outdoor temperature have an symbolic meaning, since for the values for each day were transphormed from the official database of hydrometeorological station with other time intervals than those used for the experiment.

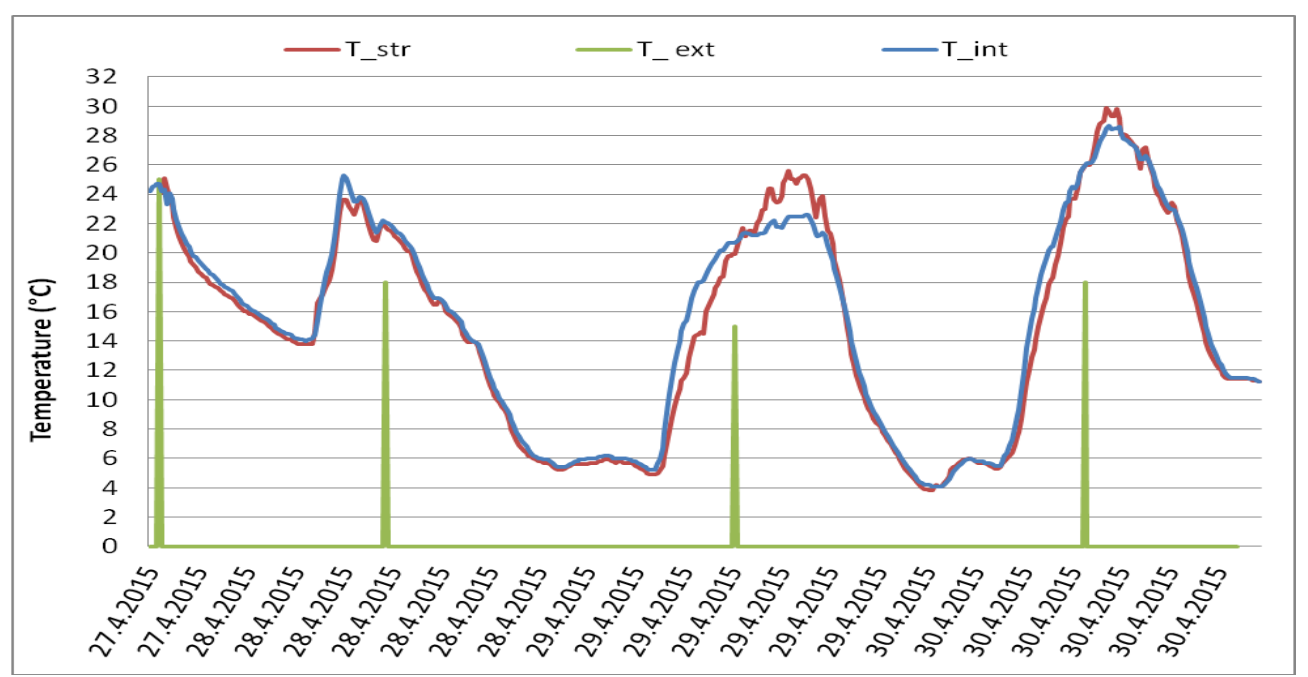

Picture 4. Green roof and an example of the indoor air (T_int), ceiling (T_str), and outdoor temperatures (T_ext) since April 27 th $21: 00$ till April 30, midnight.

Beside measured values, also calculated ones were compared. The „U-factor“ of roof with foil, and aluminium, equales $0,145 \mathrm{~W} / \mathrm{m}^{2 *} \mathrm{~K}$, for the green roof it is $0,139 \mathrm{~W} / \mathrm{m}^{2 *} \mathrm{~K}$. As far as the solar gains via roof are concerned, the model of the green roof has $13 \mathrm{~W}$ of gains. The foil, and aluminium would get almost $14 \mathrm{~W}$. These values show possible tendency the gains would be lower in the 
case of green roof than via the other two cases. The same character could have been observed in the simplified experiment.

\subsection{Analysis}

As shown in the graph above (Picture 3), the lowest tempearature value during days was measured in the case of the roof with greenery. This proves its better property to absorb outdoor gains from the air, from the sun. Speaking in percentage, the ceiling surface temperature values for the green roof were lower cca by $1,8 \%$ compare to the alluminium and by $4,8 \%$ lower to the foil. As far as the indoor air temperatures are concerned, the lowest values of the green roof was smaller then aluminium covering by $1,7 \%$ and by $2,8 \%$ then the foil.

Comparing the values between aluminium and foil, the aluminium roof has during the day lower value by cca $1,15 \%$ for the indoor air temperature and $3 \%$ for the ceiling temperature.

In most of the cases the peak temperatures are postpond to the outdoor temperature caused by the experiment building envelope. Higher indoor temperature values compared with outdoor ones are also due to the insulation character of the building envelope as well as due to the „,covered windows“ (not possible to be open, plast material, on the second floor covered with sunscreen, Picture 1)

\section{Conlusion}

The experiment was conducted to show the expected influence of the colour onto the solar gains. The values show the lowest values for green roof, and higher in the case of aluminium, and foil. Ofcourse to pronounce the results to be significant, the experiment should be run for longer time, under specific conditions, with logged outdoor temperature and solar intensity data, and detailed statistical analysis.

\section{References}

[1] STN 73 0540:1986, Výpočet tepelnej zát'aže klimatizovaných priestorov. SÚTN Bratislava, 1985.

[2] M. Halahyja, I.Chmúrny, Z.Sternová, Stavebná tepelná technika, Jaga Group, Bratislava, 1998, ISBN 80-88905-04-4.

[3] L.Krčmárová, Pasívne chladenie z hl'adiska povrchovej úpravy obalového plášt'a budovy (Passive Cooling via Colour of Envelope), STU, Bratislava, 2015 (diploma work in Slovak).

[4] B.Givoni, Man, Climate, and Architecture, Applied Science Published, Ltd, London, 1976

[5] N.K. Bansal, S.N.Garg, S. Kothari, Effect of Exterior Surface Colour on the Thermal Performace of Buildings. Building and Environment, Vol.27, No.1, pp.31-37, 1992, Great Britain 